https://doi.org/10.15407/ujpe64.2.120

V.M. KRAVCHENKO,${ }^{1}$ YU.P. RUD,${ }^{2}$ L.P. BUCHATSKI,${ }^{3}$ YE.YU. STEPANENKO ${ }^{1}$ D.V. GRYN ${ }^{1}$ V.M. YASHCHUK ${ }^{1}$

${ }^{1}$ Department of Experimental Physics, Faculty of Physics, Taras Shevchenko National University of Kyiv (64/13, Volodymyrs'ka Str., Kyiv 01601, Ukraine; e-mail: kravm@knu.ua)

${ }^{2}$ Laboratory of Biotechnology in Aquaculture, Institute of Fisheries of the Nat. Acad. of Agrarian Sci. of Ukraine (135, Obukhivs'ka Str., Kyiv 03164, Ukraine)

${ }^{3}$ Laboratory of Physico-Chemical Biology, ESC Institute of Biology, Taras Shevchenko National University of Kyiv (64/13, Volodymyrs'ka Str., Kyiv 01601, Ukraine)

\title{
SPECTROSCOPIC STUDIES OF INFECTIOUS PANCREATIC NECROSIS VIRUS, ITS MAJOR CAPSID PROTEIN, AND RNA
}

\section{Introduction}

Viral diseases belong to the most serious threats for the mankind. This is caused by an extremely high rate of infection spread, impossibility to provide a prompt effective vaccination and severe consequences for the human health and the economy. On the other hand, the viruses have become a focus of the rapt attention of physicists, because that kind of biological nanoobjects can be used as a unique template for growing metal-dielectric nanoparticles thanks to their prescribed composition, monodispersity, and accessible interior, which allows one to grow dielectric core particles with a narrow size distribution and an accessible core below $80 \mathrm{~nm}$ in diameter [1].

(C) V.M. KRAVCHENKO, YU.P. RUD, L.P. BUCHATSKI, YE.YU. STEPANENKO, D.V. GRYN,

V.M. YASHCHUK, 2019

120
Optical spectroscopy is an efficient informative method to study viruses. It provides well reproducible results and is a powerful supplement to conventional biological methods of studying the living organisms. Thus, it allows one to determine the concentration of virions in the environment or in the tissues of an infected animal. In particular, the fluorescence may be a tool to detect and image viruses, as well as to monitor their host cell interactions and the viral infection of cells. It may be a part of biodefense applications [2-4].

It has been confirmed that the energy structures of DNA, RNA, and complex protein macromolecules are determined mainly by the individual properties of their $\pi$-electron systems such as DNA or RNA nucleotides or aromatic amino acids (tryptophan, tyrosine, and phenylalanine), which are centers of intense UV absorption and fluores-

ISSN 2071-0194. Ukr. J. Phys. 2019. Vol. 64, No. 2 
cence $(\lambda>200 \mathrm{~nm})$. Some success has been reached in modeling the spectra of large and complex native biological macromolecules by the spectra of relatively small $\pi$-electron-containing model compounds [5]. At the same time, it is known that the peak positions of absorption bands and, even to a greater extent, fluorescence bands and the fluorescence quantum yield are highly dependent on the protein structure and the local environment (neighboring amino acid residues and solvent molecules) [2].

The present paper is devoted to infectious pancreatic necrosis virus (IPNV) that causes the severe disease of salmonid fishes (trout, salmon, etc.). The IPNV belongs to the genus Aquabirnavirus of the Birnaviridae family. The IPNV virion consists of two segments of a double-stranded RNA packed in a nonenveloped single-shelled icosahedrical protein capsid approximately $70 \mathrm{~nm}$ in diameter. There are five proteins in the IPNV virion, one of them, namely VP2, being the major capsid protein (i.e., viral protein that is the main component of the capsid) (up to $90 \%$ wt. of all IPNV capsid proteins) [6-9]. The IPNV major capsid protein (MCP) consists of 442 amino acids including the aromatic ones (3 tryptophans, 18 tyrosines and 13 phenylalanines) [10].

The aim of the present work was to determine the role of IPNV virion constituents (capsid proteins and viral RNA) in the formation of spectral properties of the whole IPNV virions.

\section{Experimental}

An aquatic birnavirus was isolated from rainbow trout fry, Onhorhynchus mykiss, during a fish health inspection in fish-farms in the west region of Ukraine near the rivers Siret and Cheremosh (Chernivtsi region) [11].

The virus was purified from the tissue culture supernatant by the ultracentrifugation. Then the virus suspension was used for the electron-microscopy investigation and viral RNA extraction. For electron microscopic studies, the viral suspension was stained with $2 \%$ uranyl acetate. Electron micrographs of IPNV virions are presented in Fig. 1 [11].

Genomic viral RNA was extracted from collected fish internal organs, the virus-infected cell culture supernatant, and purified virus suspension using a GeneJETTM RNA Purification Kit (ThermoScientific) as described in manufacturer's protocol.

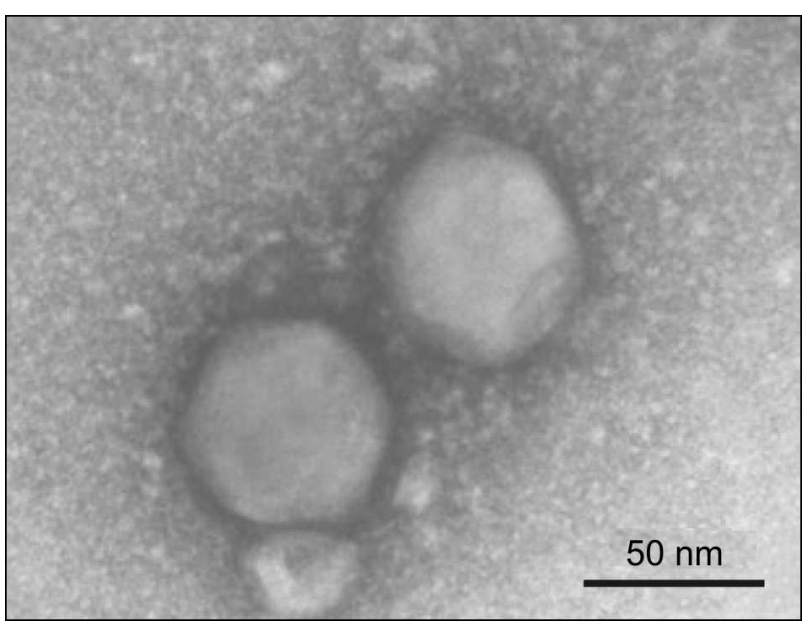

Fig. 1. Electron micrographs of IPNV virions [11]

The MCP was extracted from IPNV virions according to protocol [12].

We have measured the absorption, fluorescence, fluorescence excitation, phosphorescence and phosphorescence excitation spectra of IPNV virions, major capsid protein, and viral RNA dissolved in TRIS$\mathrm{HCl}$, TRIS-HCl-EDTA, and distilled water, respectively. The absorption spectra were recorded at room temperature with a Specord UV-VIS two-beam spectrophotometer. The fluorescence, fluorescence excitation, phosphorescence and phosphorescence excitation spectra were recorded at room and liquid nitrogen temperatures with a Varian Cary Eclipse fluorescent spectrophotometer. A pulsed xenon lamp with continuous emission spectrum was used as the excitation source. Measurements were carried out in the UV and visible spectral regions $(\lambda=200-650 \mathrm{~nm})$. The spectral width of the exit slit of a fluorescent spectrophotometer was normally $5 \mathrm{~nm}$ and did not exceed $10 \mathrm{~nm}$ for the weak fluorescence and phosphorescence spectra.

\section{Results and Discussion}

\subsection{Absorption spectra at room temperature}

The absorption spectra of whole IPNV virions, viral RNA, and major capsid protein are presented in Fig. 2. It can be seen that both RNA and MCP contribute to the IPNV virion absorption. Thus, the absorption spectrum for IPNV RNA consists of a few bands with peaks at approximately 252, 257, and $262 \mathrm{~nm}$. A similar structured absorption spec- 


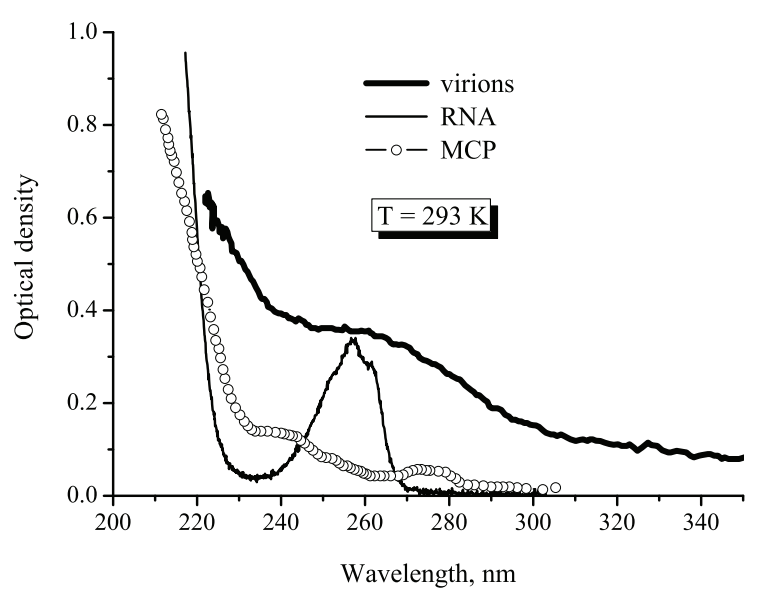

Fig. 2. Absorption spectra of IPNV virions, viral RNA, and major capsid protein. The vertical scale is arbitrary

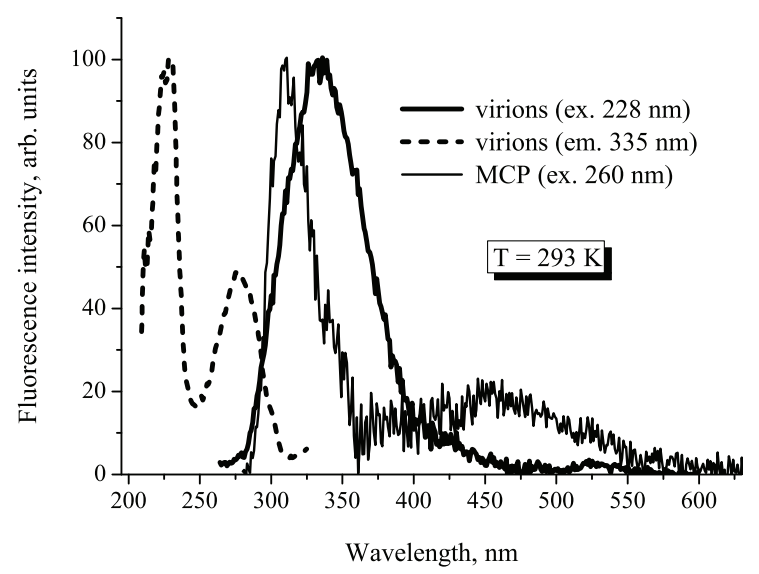

Fig. 3. Normalized fluorescence and fluorescence excitation spectra of IPNV virions and major capsid protein. Emission and excitation wavelengths are indicated in the legend

trum was reported for adenine in [13], although with somewhat different peak positions. MCP exhibits an absorption edge, whose position and slope are determined by the concentration of the protein in buffer. All spectra were corrected for the solvent absorption.

\subsection{Fluorescence and fluorescence excitation spectra}

Figure 3 illustrates the fluorescence and fluorescence excitation spectra of IPNV virions, as well as fluorescence spectra of MCP at room temperature. All fluorescence spectra of the samples were checked for the background fluorescence of the solvents. The first two types of spectra practically coincide with the respective spectra of Mosquito iridescent virus (MIV) virions described in [14]. This fact suggests that the fluorescence centers in both IPNV and MIV virions may be the same. Moreover, it was shown that the fluorescence of the whole MIV virion at room temperature was caused mainly by the fluorescence of its capsid proteins [14].

It is evident from Fig. 3 that the fluorescence spectra of IPNV virions and MCP do not coincide: they have different peak positions (335 and $310 \mathrm{~nm}$, respectively) and half-widths.

The centers of intense absorption and fluorescence in the UV spectral region $(\lambda>200 \mathrm{~nm})$ in all protein macromolecules are the aromatic amino acids $[15,16]$. In our previous work [14], we also measured the fluorescence and fluorescence excitation spectra of separate aromatic amino acids at room temperature. It was found that the peak positions and halfwidths of the spectral bands of both fluorescence and fluorescence excitation spectra of virions did not coincide with those of separate aromatic amino acids. This may be caused by the following reasons: i) amino acid fluorescence (and phosphorescence) band position is sensitive to the environment and ii) closely located aromatic amino acids may form aggregates within the protein macromolecule $[2,16]$.

As to the fluorescence spectra of IPNV virions and IPNV MCP, we can suggest that a $310 \mathrm{~nm}$ shortwave band for the MCP (the long-wave band will be discussed later) is likely to be due to the tyrosine fluorescence (similar peak positions and half-widths of the fluorescence band) [14]. Moreover, as was mentioned above, this aromatic amino acid predominates in the IPNV MCP. The larger peak wavelength and larger half-width of the virion fluorescence band may be attributed to the contribution of tryptophan, since it has a higher quantum yield and may be present in the other four proteins of the virion.

The low-temperature fluorescence spectrum of IPNV virions is a single band with a peak at 320 $330 \mathrm{~nm}$, while the fluorescence excitation spectrum consists of two bands at approximately 225 and $275 \mathrm{~nm}$.

IPNV RNA exhibits the low-temperature fluorescence band with a peak at $305 \mathrm{~nm}$, whose excitation spectrum has a peak at approximately $273 \mathrm{~nm}$ (Fig. 4). Like the IPNV RNA absorption spectrum (see Fig. 2), the fluorescence excitation one is likely 
to have a structure: one can distinguish a few peaks at 258, 266, 273, and $279 \mathrm{~nm}$.

The IPNV RNA fluorescence spectrum resembles neither RNA nucleotide one (the former has too short peak wavelength and too small half-width compared to those of either RNA base) [5], although other RNA fluorescence spectra reported in the literature can be modeled as a linear combination of fluorescence spectra of RNA nucleotides, for example, rGMP and rCMP [17]. There is a reason to believe that the different peak positions and half-widths of the RNA fluorescence (and phosphorescence) spectra in the literature and in our study may be attributed to the dependence of the shape and peak position of emission spectra of a solution of either proteins or amino or nucleic acids or nucleotides on the solvent and its $\mathrm{pH}$ index $[16,18]$.

\subsection{Phosphorescence and phosphorescence excitation spectra}

The low-temperature phosphorescence spectra of IPNV virions and major capsid protein are found to be single bands peaked at $420 \mathrm{~nm}$ that practically coincide (Fig. 5). This fact may indicate that the virion phosphorescence is mainly due to the emission of capsid proteins. The comparison with the phosphorescence spectra of aromatic amino acids alows us to suppose that both tyrosine and tryptophan contribute to the above-mentioned spectra [18].

The $420 \mathrm{~nm}$ phosphorescence band superimposes on the fluorescence spectrum of MCP at both room and liqiud nitrogen temperatures (Fig. 6), which may be caused by a short phosphorescence lifetime and the inability of a fluorescent spectrophotometer to cut off the phosphorescence signal with a lifetime of less than $1 \mu \mathrm{s}$ [19]. So, the fluorescence spectrum of IPNV MCP is a single band with a peak at $310-320 \mathrm{~nm}$, which may be related to tyrosine.

The phosphorescence spectrum of IPNV RNA has quite a different shape. It exhibits the electronicvibrational structure with distinct bands at approximately 400, 430, $460 \mathrm{~nm}$ and longer wavelengths, the first three bands having identical excitation spectra (Fig. 7). On some samples of IPNV RNA, we also observed a short-wave phosphorescence peak at approximately $370 \mathrm{~nm}$ under the same excitation conditions. Figure 8 illustrates the emission spectrum from Fig. 7 recalculated as the number of photons

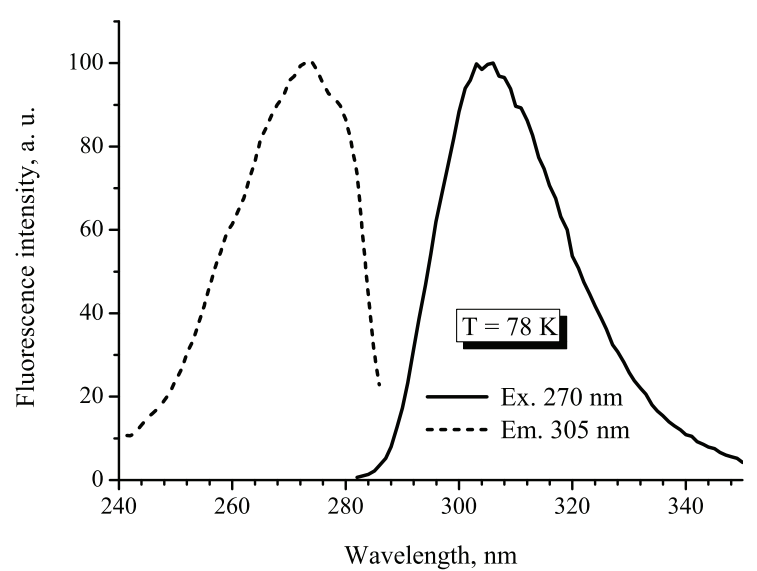

Fig. 4. Normalized fluorescence and fluorescence excitation spectra of IPNV RNA

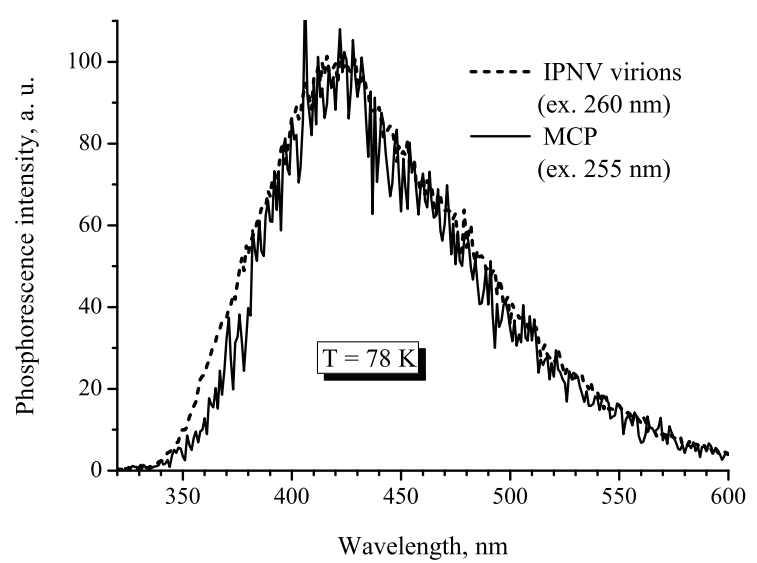

Fig. 5. Normalized phosphorescence spectra of IPNV virions and major capsid protein

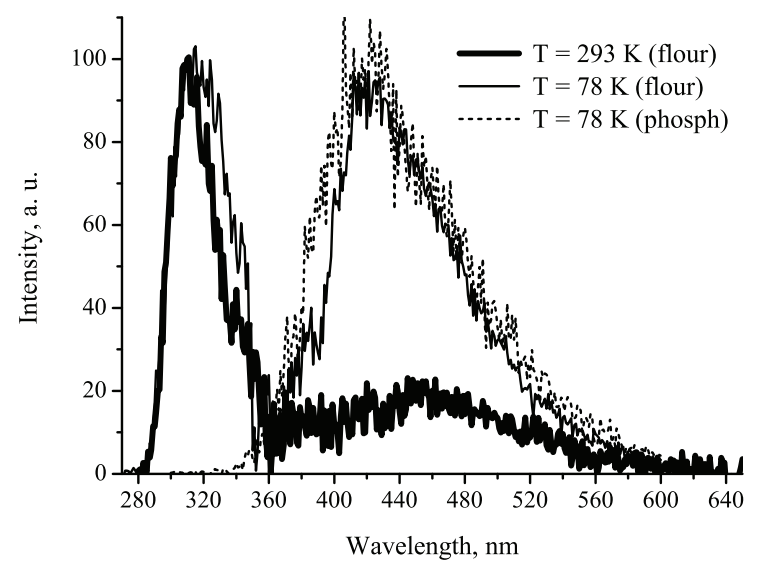

Fig. 6. Normalized fluorescence and phosphorescence spectra of IPNV major capsid protein at room and liquid nitrogen temperatures 


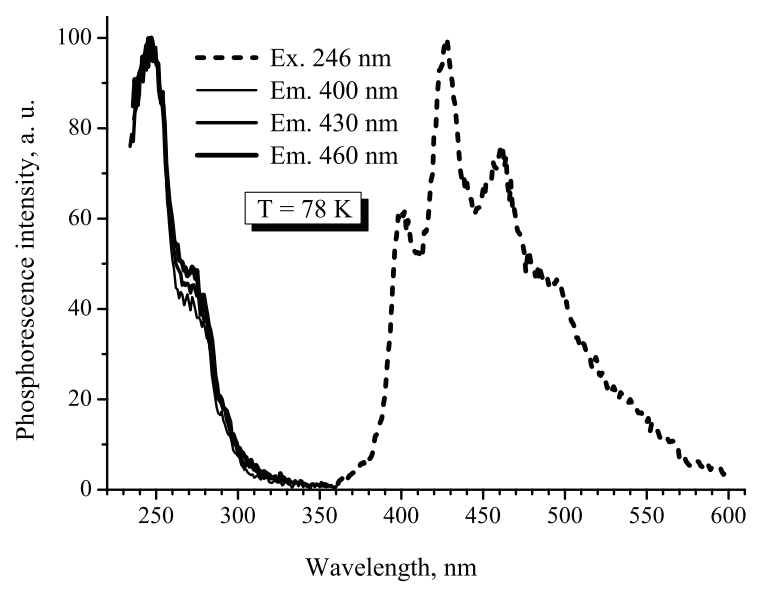

Fig. 7. Normalized phosphorescence and phosphorescence excitation spectra of IPNV RNA

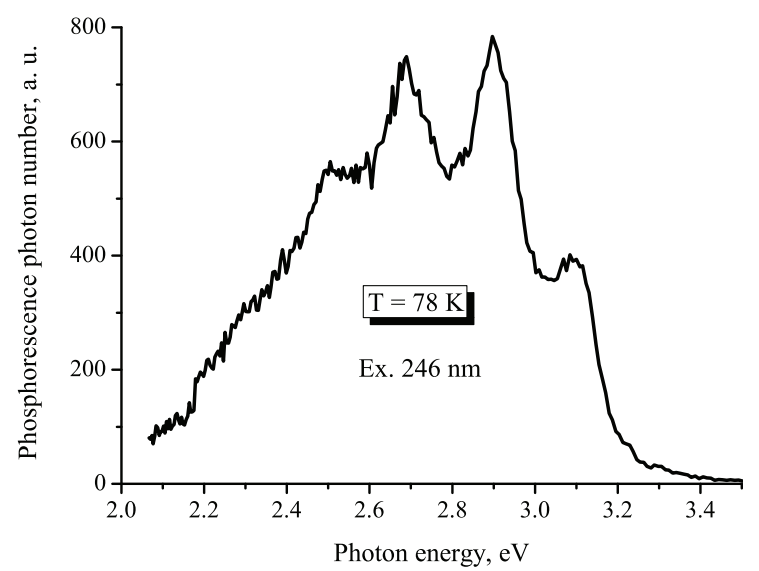

Fig. 8. IPNV RNA phosphorescence spectrum recalculated as the number of photons vs their energy

vs their energy. One can see distinct peaks at 3.1, $2.9,2.7$, and $2.5 \mathrm{eV}$. This electronic-vibrational structure of the spectrum may be attributed to that of the phosphorescence of adenine, because this nucleotide has the lowest first triplet energy level among all RNA nucleotides and because of the fact that the triplet excitation can be freely transferred along the RNA macromolecule $[5,17]$. Some discrepancy in the peak positions in RNA and adenine phosphorescence spectra may have the same causes as described above.

From Figs. 5 and 7, one can conclude that the lowtemperature phosphorescence of IPNV virions can be attributed to that of capsid proteins rather than viral RNA.

\section{Conclusions}

It is shown that the UV absorption of IPNV virions is caused by the absorption of both capsid proteins and viral RNA. The fluorescence of IPNV MCP may be attributed to the emission of tyrosine, while the fluorescence of IPNV virions to that of both tyrosine and tryptophan. The low-temperature phosphorescence of virions can be attributed to that of capsid proteins rather than viral RNA. The IPNV RNA phosphorescence spectrum exhibits the electronicvibrational structure and may be due to the emission of adenine links.

1. C. Radloff, R.A. Vaia, J. Brunton et al. Metal nanoshell assembly on a virus bioscaffold. Nano Lett. 5, 1187 (2005).

2. A. Alimova, A. Katz, R. Podder et al. Virus particles monitored by fluorescence spectroscopy: A potential detection assay for macromolecular assembly. Photochem. Photobiol. 80, 41 (2004).

3. Going viral. Bioprobes 67, 6 (2012) [http:// lifetechnologies.com].

4. K. Takemura, O. Adegoke, N. Takahashi et al. Versatility of a localized surface plasmon resonance-based gold nanoparticle-alloyed quantum dot nanobiosensor for immunofluorescence detection of viruses. Biosen. and Bioelectron. 89, 998 (2017).

5. V.M. Yashchuk, V.Yu. Kudrya, S.M. Levchenko et al. Optical response of the polynucleotides-proteins interaction. Mol. Cryst. Liq. Cryst. 535, 93 (2011).

6. P. Dobos, T.E. Roberts. The molecular biology of infectious pancreatic necrosis virus: a review. Can. J. Microbiol. 29, 377 (1983).

7. L. Perez, P.P. Chiou, J.-A.C. Leong. The structural proteins of infectious pancreatic necrosis virus are not glycosylated. J. Virol. 70, 7247 (1996).

8. S. Lauksund, L. Greiner-Tollersrud, C.-J. Chang, B. Robertsen. Infectious pancreatic necrosis virus proteins VP2, VP3, VP4 and VP5 antagonize IFNa1 promoter activation while VP1 induces IFNa1. Virus Research 196, 113 (2015).

9. A.K. Dhar, S. LaPatra, A. Orry, F.C.T. Allnutt. Infectious pancreatic necrosis virus. In Fish Viruses and Bacteria: Pathobiology and Protection, edited by P.T.K. Woo and R.C. Cipriano (CABY Publishers, 2017) [ISBN: 9781780647784].

10. Structural polyprotein. Infectious pancreatic necrosis virus (strain Jasper) (IPNV) [http://www.uniprot.org/ uniprot/P05844].

11. Yu.P. Rud, M.I. Maistrenko, L.P. Buchatskiy. Characterization of an infectious pancreatic necrosis virus from rain-

ISSN 2071-0194. Ukr. J. Phys. 2019. Vol. 64, No. 2 
bow trout fry (Onhorhynchus mykiss) in West Ukraine. Virologica Sinica 30, 231 (2015).

12. Purify proteins from polyacrylamide gels. Thermal Scientific. Tech. tip \# 51 [www.thermo.com/pierce].

13. M. Tanaka, S. Nagakura. Electronic structures and spectra of adenine and thymine. Theoret. Chim. Acta (Berl.) 6, 320 (1966).

14. V.M. Kravchenko, Yu.P. Rud, L.P. Buchatski et al. Spectroscopic studies of mosquito iridescent virus, its capsid proteins, lipids and DNA. Ukr. J. Phys. 57, 183 (2012).

15. P.G. Kostyuk, D.M. Grodzinsky, V.L. Zima et al. Biophysics (Vyshcha Shkola, 1988) (in Russian).

16. J.R. Lakowicz, Principles of Fluorescence Spectroscopy (Springer Science+Business Media, 2006) [ISBN-10: 0-38731278-1, ISBN-13: 978-0387-31278-1].

17. V.M. Yashchuk, V.Yu. Kudrya, V.M. Kravchenko, M.Yu. Losytskyy. Introduction to Biophotonics (Chetverta Khvylya, 2018) (in Ukrainian).

18. T. Truong, R. Bersohn, P. Brumer et al. Effect of $\mathrm{pH}$ on the phosphorescence of tryptophan, tyrosine, and proteins. J. Biol. Chem. 242, 2979 (1967).

19. Varian Cary Eclipse fluorescence spectrophotometer. User's manual.

Received 20.11.18
В.М. Кравченко, Ю.П. Рудъ, Л.П. Бучачъкий, Є.Ю. Степаненко, Д.В. Гринъ, В.М. Ящук

СПЕКТРОСКОПІЧНІ ДОСЛІДЖЕННЯ ВІРУСУ ІНФЕКЦІЙНОГО ПАНКРЕАТИЧНОГО НЕКРОЗУ, ЙОГО ГОЛОВНОГО КАПСИДНОГО БІЛКА ТА РНК

Р е $з$ ю м е

Вірус інфекційного панкреатичного некрозу (ВІПН) викликає серйозні захворювання риб сімейства лососевих (форелі, лосося тощо). Віріон ВІПН складається з дволанцюгової вірусної РНК, оточеної білковим капсидом. Метою роботи було визначення ролі складових віріона ВІПН (капсидних білків та вірусної РНК) у формуванні спектральних властивостей цілих віріонів. В УФ та видимій областях спектра було виміряно спектри поглинання, флюоресценції, збудження флюоресценції, фосфоресценції та збудження фосфоресценції віріонів ВІПН, головного капсидного білка та вірусної РНК, розчинених у різних буферах. Показано, що поглинання віріонів в УФ області спектра зумовлене поглинанням як капсидних білків, так і вірусної РНК. Флюресценція головного капсидного білка та цілих віріонів може бути зумовлена флюоресценцією тирозину та тирозину + триптофану відповідно. Низькотемпературна фосфоресценція віріонів зумовлена, скоріш за все, фосфоресценцією капсидних білків, а не вірусної РНК. У спектрі фосфоресценції вірусної РНК спостерігається електронно-коливальна структура, яка може відповідати аденіну. 